\title{
The Lister Centenary Celebrations in London.
}

O) April 5, 1827, there was born at Upton, in Essex, one who was destined to achieve more for the happiness of mankind than was vouchsafed to almost any other human being. Joseph Lister was the fourth child and second son of Joseph Jackson Lister, a prosperous wine merchant and also an eminent scientific worker, and fellow of the Royal Society, to whom we owe the production of the achromatic lens. He studied medicine at University College, London, and in $\mathbf{1 8 5 2}$ took the M.B. degree and became also a fellow of the Royal College of Surgeons.

Acting on Prof. Sharpey's advice, Lister then went to Edinburgh, where he became closely associated with the famous surgeon James Syme, and in 1856 he married Agnes, Syme's eldest daughter. In 1860 he was appointed professor of surgery in the University of Glasgow, a post which he held for nine years, only leaving when he was elected to the Edinburgh professorship. In 1877 he was appointed to the chair of clinical surgery at King's College, London, and held this post until 1893. In 1883 he was made a baronet. In 1895 he became president of the Royal Society, and during his tenure of this office, was created a peer, on the occasion of Queen Victoria's second jubilee. At the time of King Edward's coronation he became a member of the Order of Merit. In 1908 he retired to the small seaside town of Walmer, in Kent, where four years later, on Feb. 10, he passed peacefully away, at the age of eighty-four. Lady Lister had predeceased him by some nineteen years.

This bald sketch of Lister's life will enable readers to follow more clearly the account which follows of the celebrations during the Lister centenary week in London, in which the speakers dealt with the various aspects of his life and work. For further details those interested may be referred to the chapter on the Life of Lord Lister in the Handbook of the Lister Centenary Exhibition at the Wellcome Historical Medical Museum. ${ }^{1}$ The Glasgow period is dealt with by Sir Hector Clare Cameron, ${ }^{2}$ and in the centenary contribution entitled "Lister and the Lister Ward in the Royal Infirmary of Glasgow," 3 wherein accounts are given of the beginnings of antiseptic surgery and of the fruitless efforts made by scientific men the world over to save the Lister ward from demolition : the Edinburgh period is described in interesting detail by Dr. J. R. Leeson. ${ }^{4}$

The centenary celebrations commenced in London on Monday, April 4, when about a hundred delegates from all parts of the world were received by the King at Buckingham Palace. An address was presented by Sir Ernest Rutherford, president of the Royal Society, to which His Majesty replied.

1 Lister Centenary Exhibition at the Wellcome Historical Medical Museum : Handbook, 1927, (The Wellcome Foundation, Ltd., London.) 2 "Centenary of Lord Lister, 1827-1927. Reminiscences of Liste and of his Work in the Wards of the Glasgow Royal Infirmary, 1860 1869. By Sir Hector Clare Cameron. (Glasgow University Publications, 6.) Pp. $45+3$ plates. (Glasgow: Jackson, Wylie and Co. 1927.) is. net.

"Lister and the Iister Ward in the Roval Infirmary of Glasgow: a Centenary Contribution" Pp. xvi $+132+28$ plates, (Glasgow: Jackson. Wylie and Co., 1927.) $12 s .6 d$. net

" "Lister as I knew Him", By Dr John Rudd Leeson Pp xii + $12+7$ plates. (London: Baillière, Tindall and Cox, 1927.) $8 s .6 d$. net.
In the afternoon the Listerian Society held a meeting at King's College Hospital, with Mr. Arthur Cheatle in the chair. Sir Watson Cheyne, in the course of his address, said that the outcome of Lister's work was perhaps more widespread than that of any of the great statesmen, generals, philosophers or religious teachers, and its influence on mankind was not limited to any country or race. Sir Watson described how he himself, with a few other chosen associates, accompanied Lister from Edinburgh to King's College Hospital as apostles of the new methods in surgery. Like all pioneers, Lister met with much opposition in promulgating his views, and London was probably one of the last places in the world to accept them. The speaker referred also to Lister's conscientiousness, both in the treatment of his patients and in his lectures: for the latter he endeavoured, by his own experiments, to prove any points which appeared to him doubtful. The difficulties in advising treatment were greatly enhanced by the fact that only some surgeons practised antisepsis ; thus an operation which might be justifiable, performed antiseptically, would be contra-indicated if the additional risk of sepsis had to be run.

In the evening a reception was held at the Royal Society of Medicine, when Sir St. Clair Thomson gave an address entitled "A House Surgeon's Memories." He said that Lister achieved more for mankind than all the surgeons from the beginning of history. For centuries the results of surgical wounds had scarcely improved at all: but Lister's teaching has saved more lives than all the military heroes of all the ages have destroyed. Sir St. Clair was associated with Lister at King's College Hospital; at his inaugural lecture he described experiments showing that neither milk nor blood had any inherent tendency to putrefaction, and if drawn under what we should call 'sterile' conditions, would remain free from putrefaction indefinitely. Lister's classes were strangely neglected by the students, probably owing to the fact that his work did not find favour with the examiners of the period, so that his teaching was of little use in helping a man to pass his examination. London was not backward in demonstrating that a prophet was not without honour except in his own country. But in ten years' time, with a new generation of surgeons springing up, Lister's technique had become widely followed. Sir St. Clair referred also to his scientific spirit. In 1875, Queen Victoria, to whom only one side of the question had been presented, wrote to Lister asking him to take action to suppress vivisection. Lister wrote to the private secretary as follows: "I should deeply regret that $I$ cannot see my way to comply with this request, were I not persuaded that my duty so would not promote the real good of the community, which I know to be Her Majesty's only object in the matter."

On Tuesday, April 6, the delegates to the centenary celebrations were received by the Prime Minister in the Great Hall of the British Medical

No. 2998, VoL. 119] 
Association, Tavistock Square. Sir Ernest Rutherford was in the chair and was accompanied by Mr. R. G. Hogarth, president of the British Medical Association. Sir Ernest, in the course of a few introductory remarks, said that it was not necessary to be a specialist to recognise the debt the whole world owes to Lister's discoveries and his singleminded devotion to the cause of suffering humanity. Mr. Baldwin recalled that it was two years after Lister came to London, and before he had obtained that recognition which was afterwards lavished upon him, that at an international congress in Amsterdam, he was greeted by the chairman in these words : "Prof. Lister, it is not only our admiration which we offer you; it is our gratitude and that of the nations to which we belong." These words were echoed years later, not by an Englishman but by an American, at a dinner of the Royal Society, when Mr. Bayard, the American Ambassador, in proposing Lister's health, said : "My lord, it is not a profession, it is not a nation, it is humanity itself which with uncovered head salutes you." The Prime Minister said that they had come to greet the memory of a great master workman in his own craft, the man who pursued his science empirically and who also, by applying newly discovered knowledge to practical problems throughout his life, brought more relief and comfort to the human race than almost any man who has lived. At the same time, as a statesman he (Mr. Baldwin) felt he could pay tribute to Lister's character, his wonderful simplicity and integrity, for he was a man who loved the truth, gentle and filled with charity and self-devotion, a man with never a mean thought.

After the Prime Minister had greeted each delegate, Prof. Henri Hartmann of Paris and Prof. Max Ritter von Gruber, of Munich, spoke on the influence Lister's practice had on pathological and surgical science and practice in their own countries.

On Wednesday, April 6, a thanksgiving service was held in Westminster Abbey, in the morning, which was attended by the delegates, and by representatives of the Royal Society and of the Royal Colleges of Surgeons and Physicians. The service was conducted by Canon Nixon, and the Bishop of Birmingham, Dr. E. W. Barnes, delivered an address. He said that Lister owed much to his Quaker ancestry, and perhaps it was not fanciful to see in the ability of his father, and in a touch of Celtic imagination derived from his mother, the source of his genius. He certainly received in his home life influences which made his character the worthy servant of his genius. Throughout his life he retained the Christian faith of his childhood: at the time of his marriage he ceased to belong to the Society of Friends and became, like his wife, a member of the Scottish Episcopal Church. He combined the hope of personal immortality with faith in the goodness of the Creator, and when his life was drawing to a close, he publicly expressed his conviction that "there is no antagonism between the religion of Jesus Christ and any fact scientifically established." He was convinced of the power of goodness and was a loyal servant of the truth. Dr. Barnes continued by saying that man differs from all other animals in possessing a soul. Is it possible that, by virtue of the mental powers which set man apart, he will conquer disease and pain and thus, in the end, prepare the way for a Kingdom of God upon earth? Will medical and moral victories combine to make human life equal to human hopes? The achievements of great men give substance to our hopes, and we thank God, he said, for the example of a single-minded devotion to science which will inspire others to work for the welfare of the human race.

In the afternoon a meeting was held at the rooms of the Royal Society of Medicine, at which tributes were paid to Lister as physiologist, bacteriologist, and surgeon. Sir Ernest Rutherford was again in the chair.

Sir Charles Sherrington spoke on Lister as a physiologist. He said that Lister's first paper, published when he was twenty-five years of age, was on the "Contractile Tissue of the Iris," done with the microscope, which he used for the study of function rather than of form alone. It was only natural, considering the interest his father took in optical science, that young Lister should employ the microscope in his first research. His second paper was on the involuntary muscle cells of the skin, and it is of interest to note, in connexion with his later characteristics, certain expressions used in these papers, such as " the grand discovery of plain muscle cells" and "the beautiful muscle of the iris." These phrases throw light on the eagerness with which he threw himself into research. 'These papers reveal points in Lister's original nature : a catholic enthusiasm for research and a restless testing of authority by observed fact : in short, a fear of nothing except of missing the truth. Four years later, a further paper on involuntary muscle appeared, in which Lister proved, once again, its cellular nature; but this was the last on this particular theme: his interests had turned to surgery and pathology and his physiological research became merely collateral to the pathological studies engaging his main thoughts. His earlier work in this field was related to the problems of inflammation, and dealt with the nervous control of arteries and the inhibitory nature of certain visceral nerves; but after the year 1859 none of his work was directly related to physiology. Yet by means of his work on antisepsis and by the development of his surgical technique he enriched physiology with the contribution of enhanced means towards its own cherished aims. Without Lister's surgical principles, how could Pavlov have achieved his epoch-opening study of the digestive processes, or Ferrier initiated his work on localisation of cerebral function? How could the Toronto physiologists, barely four years ago, have bestowed upon diabetic sufferers that merciful remedy insulin? The experimentalist indeed owes to Lister an instrument of research the beneficent future of which the boldest imagination may well halt to set limit to. At the same time, while 
helping man to mastery over disease alike for animal and man, he contributed to free that necessary experimentation from the infliction of pain. Thus it is that through the years to come, after indeed the actual physiological papers may have become matter chiefly for the historian and antiquarian, Lister will still receive his meed of commemoration from the physiologist and experimentalist. It is therefore with peculiar gratitude that the physiologist brings his tribute of admiration and veneration to the memory of one great even among the greatest of the benefactors of humanity, Joseph Lister.

Prof. William Bulloch then gave an account of Lister as a pathologist and bacteriologist. The main part of the address covered the same ground as that of the article entitled "Some Aspects of Lister's Scientific Work," which Prof. Bulloch contributed to our issue on April 9, p. 531.

In the third and final address Sir Berkeley Moynihan paid an eloquent tribute to Lister as a surgeon. He said that seldom is a great discovery the product of one man's mind: in the work of other men it has ancestors-forerunners possessing one or more attributes the final and felicitous association of which within new work constitutes new truth. The claim may then arise that those who have revealed isolated and antecedent truths have priority in the final discovery. Such truths are, however, only progenitors, with no claim to be regarded as their own descendant-the new truth itself. Lister did for the craft of surgery what John Hunter had done for its science. When he first began his work, operations were few owing to the danger of putrefaction in the wound, followed in almost all cases by death. Even the simplest operation was a great anxiety to the surgeon, from the ever-present fear of suppuration developing. Lister's discovery was very gradual. His earliest surgical inquiries dealt with inflammation and the coagulation of the blood, but his chief interest lay always in the problem of the healing of wounds. $\mathrm{He}$ had arrived at the conclusion that the essential cause of suppuration in wounds was decomposition brought about by the atmosphere acting upon blood and serum retained in them, or upon portions of destroyed tissues, but since oxygen was considered to be the agent causing this putrefaction, it appeared hopeless to devise a method by which suppuration might be prevented. But when Pasteur had shown that putrefaction was caused by minute organisms suspended in the air, a method of prevention at once came to his mind, to apply to the wound some substance which would destroy the micro-organisms without injuring the body tissues. Still later he developed a method by which the organisms might be destroyed before they had even entered the wound. Around every step of his advance fierce controversy raged; the scepticism of early contemporaries was stupid, unimaginative,-and petty. But the history of science frequently discloses this bitter opposition to new truths, as in the case of Harvey and Pasteur and other famous men. Lister's answer was unfaltering continuance in inquiry and experiment, with demonstration of his results. The heavily infected wounds seen during the War has enabled us to realise much more acutely the problems which confronted Lister at the beginning of his work, and has increased our admiration for the way he overcame them. Although Lister sought to destroy the organisms which might enter a wound, yet he was not blind to the natural resistance of the body's cells to infection, so that a natural step was the development of aseptic surgery in which organisms are prevented from entering a wound so far as possible, and any that do can then be dealt with by the body's own bactericidal forces. There is no real clash between ' antiseptic' and 'aseptic' methods, for no surgeon ever practised with success a method which omitted the use of agents for the destruction of organisms. The consequences of Lister's work were many and far-reaching: when the few operations which were practised in those days became safe it was obvious that others might be attempted, and thus has grown up the science and art of modern surgery. Ovariotomy was one of the first operations to be made safe; and once it was found that the abdomen could be safely opened, a vast field of usefulness was before the surgeon. The cranial and thoracic cavities then became accessible to surgical methods of treatment, so that nowadays almost all parts of the body can be safely submitted to surgical operation. Not the least of the debts we owe to Lister is the curability of cancer if complete surgical removal is practised in the early stages of the disease. We may almost claim that the full effect of Lister's work is now accomplished. The art of surgery is far in advance of the sciences on which its future progress depends. The great search must be for methods of applying new discoveries in other sciences to the study of disease.

To the honoured dead we raise our monuments; but Lister's living and enduring memorial is a great and even greater multitude of men, women, and children of every nation, of every race, of every creed, through his mercy and by the skill of his most gentle hand relieved from infirmity and suffering and sorrow and made for a time triumphant over death itself. It is immortal Lister we salute to-day, the supreme benefactor of mankind.

In concluding, attention must be directed to the Lister Centenary Exhibition at the Wellcome Historical Medical Museum in Wigmore Street. The collection was opened by Sir W. Watson Cheyne, in the absence of Mr. Wellcome, on the evening of Thursday, April 7. The most striking exhibit is probably the section of the old Lister Ward from the Glasgow Royal Infirmary, in which Lister practised his antiseptic system of surgery between 1861 and 1869. The furniture and fittings are from the Ward when it was demolished in 1924. The collection comprises an extensive and highly interesting series of exhibits relating to all aspects of Lister's life and work, including instruments and apparatus used by him, reproductions of various experiments performed by him, his diplomas and certificates, and photographs of those associated with him in his work.

No. 2998, VoL. 119] 